\title{
Developing Manufacturing Application using Enterprise Resource Planning Concept
}

\author{
Ika Winda Lestari \\ Udayana University \\ Engineering Faculty \\ Department Information \\ Technology
}

\author{
I Made Sukarsa \\ Udayana University \\ Engineering Faculty \\ Department Information \\ Technology
}

\author{
I Ketut Adi Purnawan \\ Udayana University \\ Engineering Faculty \\ Department Information \\ Technology
}

\begin{abstract}
Information of Technology has bound in modern life especially manufacturing company with many kinds of complexity processes, machines, tools, human resources and materials to gain profit. The company need the integrated system for handle the problem. It can increase performance and efficiency so company can reach the business goals. Enterprise Resource Planning (ERP) is a concept that can be used for handle organization complexity. ERP managing many business processes to be an integrated system that occurred in manufacturing companies such as production scheduling process. Production schedule used in the business process for efficiency time and cost. Implementation of ERP used in software Odoo 8.0 with open source system for ERP which can customize based on the user. Production schedule in Odoo working automatically different with convensional system.
\end{abstract}

\section{Keywords}

Manufacturing Company, Integrated System, Production Schedule, Enterprise Resource Planning, Odoo 8.0.

\section{INTRODUCTION}

Technology development was made a lot of effect, especially for the system and technology. It caused system integrated with any computer in a network but it can use based on right access for every user and their job. The manufacturing company has scheduling and production controlling that manage the production process. Production management is controlling activity that was made as decision and related to production so goods and service produced based on quantity specification, quality, and on scheduling time with minimum cost [1].

Manufacture company using scheduling for managing many customer orders. Scheduling is organization process, selection and lead time for each job [2]. There are many reasons scheduling very important in business process, because it will increasing performing otherwise make the customer satisfied with the order can be finished on time.

Enterprise Resource Planning (ERP) is the development from Manufacture Resource Planning II (MRP II) and Material Requirement Planning evolution, but MRP focus on manufacture only but ERP handle manufacturing, logistic, distribution, inventory, invoice and accounting [3].

\section{RESEARCH METHODOLOGY}

Applications development consist of six stages that is literature research, data collecting, data processing, implementation in Odoo, testing and implementation system also conclusion and suggestion.

\section{Literature Research}

The literature research is the stage to determine ERP concept, ERP modules and its implementation on Odoo, code for Odoo customize and things about manufacturing. Literature research based on books, journals and expert research.

\section{Data Collecting}

Interview and object observation is part from Data Collecting. Interview is technic where the researcher make a dialogue with respondent to gain information. Observation is method that work directly about how process, procedure and any problem goes to every business process [4].

\section{Data Processing}

Data processing consist of Bussiness Process Management (BPM) is about business process workflow and Bussiness Process Reenginering (BPR) is how to improvement or repair business process.

\section{Implementation in Odoo}

A new business process management or the result of redesign business process can be implementation in Odoo with doing customation using Python programming code, module adjustable or workflow business process. Programming code is about how business process working on every module, and coding is solution to make it work together.

\section{Testing and Implementation System}

Testing is the most important parameters in business process implementation if developing application work successfully or neither. Testing also be decision if system application must be repair whether continue implementation system. The most important thing that must be attention is the efficiency of application on handling every business process.

\section{Conclusion and Suggestion}

Conclusion is the result on the research, can achieve the goals and how all process works through the research. Otherwise Suggestion is about things that could be doing based on this research, like development or complement.

\section{REVIEW OF LITERATURE}

System is component in Information Technology. System can be explained as connection things that integrated each other. System based on Roman "Systema" and Greece "Sustema" that has definition of system is components or elements connected for facilitating information flows. Combination between human, facilities or technology, media, procedure and control was made the important communication networking, management support, intern and ekstern user and basic decision interpretation [5].

\subsection{Enterprise Resource Planning (ERP)}

Enterprise Resource Planning (ERP) is system and technology development especially computer technology development. 
Flexibility, saving cost and application efficiency in business is the most wanted things because it can increasing business competition. Consequences on building a new system must understanding the evolution of ERP system and the latest company profile[6].

ERP is software package application with integrated modules for supporting various business function enable using data between different department. "Ref [7] ERP is efforts integrated system who manage by operation majority in a company. Difference ERP and conventional system is about system function. ERP integrated in a system meanwhile conventional system is separated system".

\subsection{Production Scheduling}

Definition of scheduling is about how time, cost, resources (tools or/and human) and jobs can working together on making a product. Scheduling can be explained as a decision on making assignment and time for working using human resources, tools, and facilities for production process [8]. The other explanation of scheduling is about instructions or indications about what must to do, with whom, and tools for finishing a job in specific time [9].

\subsection{Odoo Application}

Odoo is open source integrated enterprise resource planning software that formerly named OpenERP then changed by the developer. Odoo has client and server component. Server handle business logic and communication with database application while client provide information to user and enable operated with server using client application.

Odoo has integrated modules that can handle company complexity. Available modules in Odoo is manufacturing resource planning, sales management, purchase management, warehouse management, customer relationship management, social network, invoicing and payment, human resource management, project management, and google docs integration.

\subsection{Bussiness Process Reengineering (BPR)}

Business Process reengineering (BPR) is the redesign of business processes and the associated systems with organizational structures to achieve improvement in business performances [10].

Reengineering is redesign of business processes to achieve dramatic improvement in critical, contemporary measures of performance such as efficiency cost, service quality and speed perform[11]. Bussiness Process Reengineering is about repairing the last business process into a better business process that can using for replacing the old business process.

\section{IMPLEMENTATION}

\subsection{Database and User Right Access Configuration}

Database configuration is the first step before using the application. The function of database configuration for data saving on every input data by user.

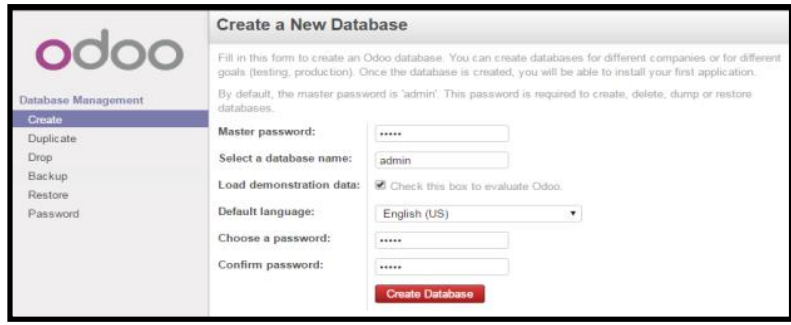

Fig 1: Database Configuration

Another step after database configuration is user right access configuration. Every single department has user with different right access. User on the application are Sales, Invoicing Purchase, Warehouse, Manufacturing and Administrator. Administrator is the one and only can access every department on the application.

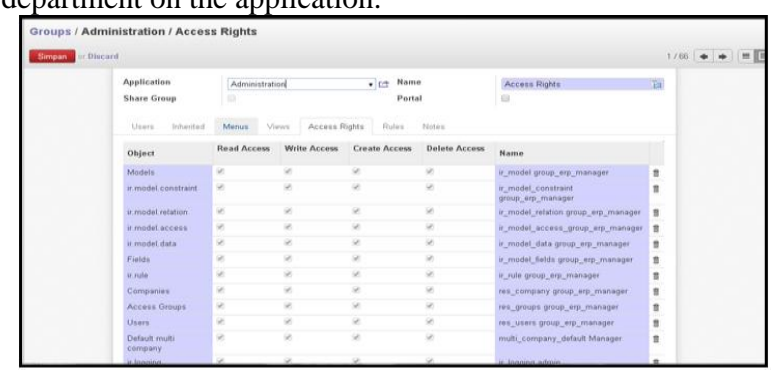

Fig 2: User Right Access Configuration

After the configuration step, setting module for customation. Go to "Settings" menu. The order is Settings-Users-UserAdministrator-Edit. Give tick on "Technical Features" and new module could install on the application using Settings menu and choose Modules. The next step is Apply Scheduled Upgrade for using the new module.

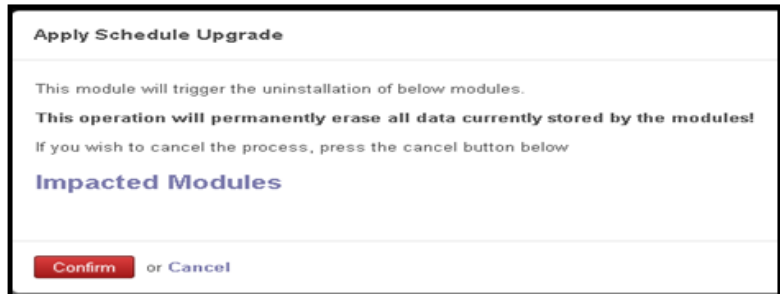

Fig 3: Apply Scheduled Upgrade

Confirming Apply Scheduled Upgrade could update module list on the application especially on manufacturing menu and production using production scheduling.

\subsection{Display of Application}

Application views is website that can be access using localhost. User can access the application everywhere without internet, but it doesn't decrease perform of the application. The main page is an opening display applications on website can be seen in Figure 4. 


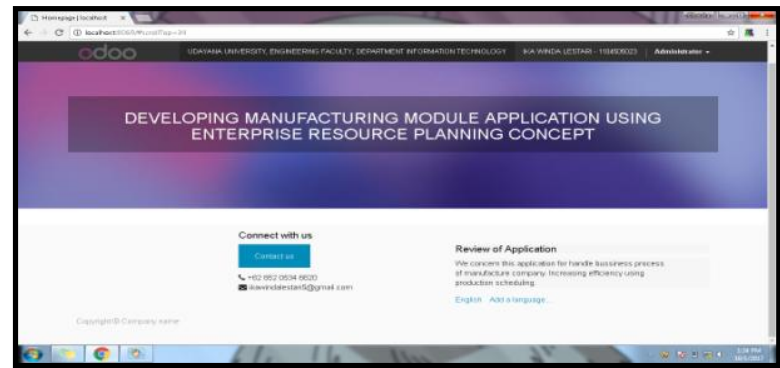

Fig 4: Opening Application Display

Opening Application Display is showing the name of the application, contact person and also the review of application. User login by using access right at the top right on the website like administrator that can see on opening application display.

Sales Orders must first made by the sales department, but to desired date in completing the order must be approved by Admin, Manufacturing Manager, or Warehouse Manager. Sales Orders that have been approved will used as a Manufacturing Order (MO) which is used to section for the Manufacturing production process.

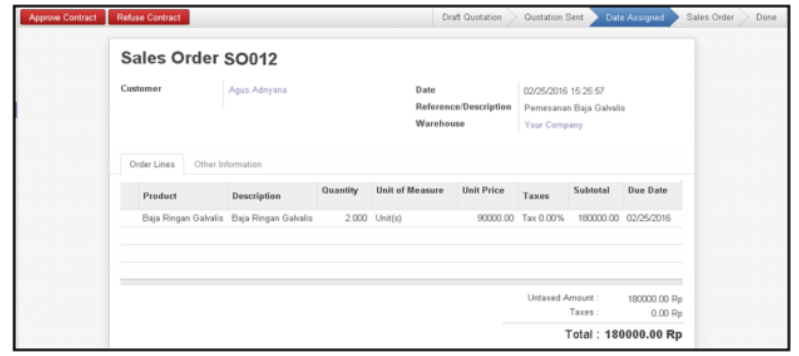

Fig 5: Sales Order Form

SO that has been approve by the sales department will display the form that is validated by the department Invoicing, due to the form of payment-related by the customer to the company.

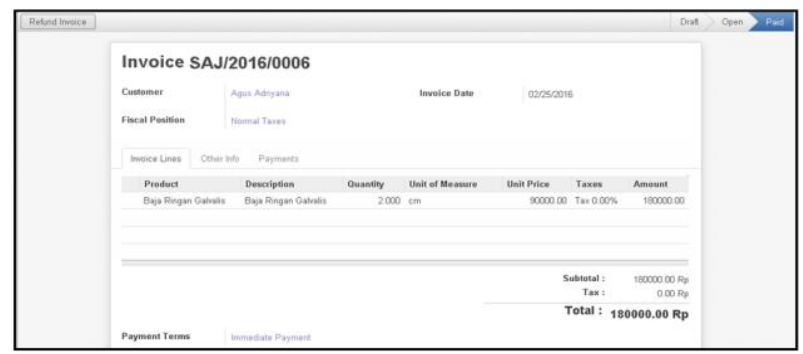

Fig 6: Customer Invoice Form

Invoice that contains the customer's name, amount paid, method of payment and date of payment. The amount paid is not to be paid off, but can be paid half beforehand or according with an agreement with the company's customers. After the process of making the next payment handling Manufacturing Orders regarding production orders made by Sales Orders.

Display Manufacturing Order form can be seen in Figure above. It displays the contents of Manufacturing Order form used in production process with production schedule. There are few column describe detail bill of material that using in making product.

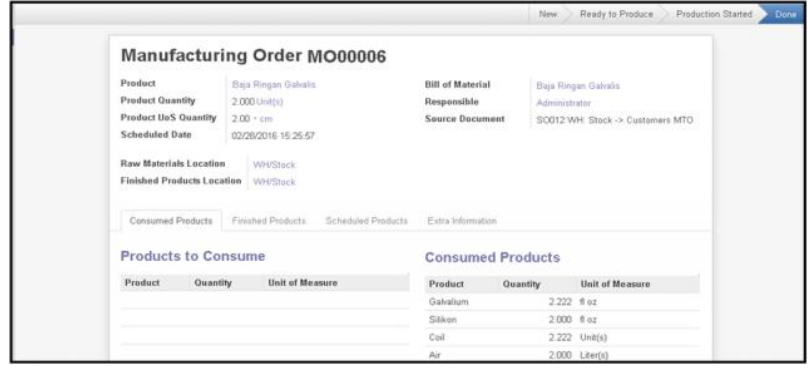

Fig 7: Manufacturing Order Form

After the manufacture of the next MO is the Procurement Order, handles based on demand after the order of Manufacturing Order status completed.

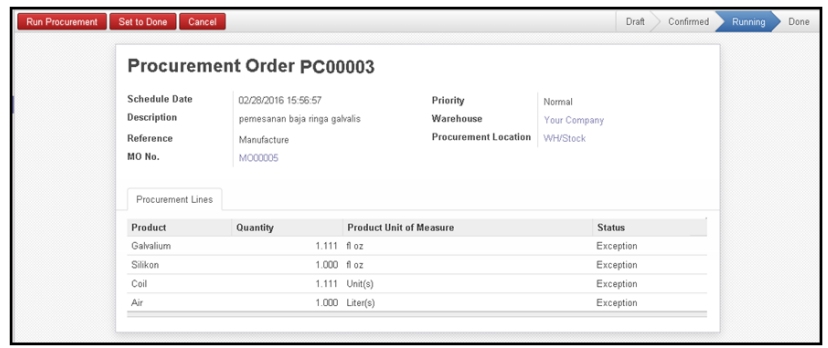

Fig 8: Procurement Order Form

Form PO that has been processed, the status will change from "Confirmed" to "Running" which means the production process in accordance with the MO request being worked. Once the process is complete, the status will change to "Done" or if the process can be completed before the scheduled time, it can be clicked the "Set to Done" so that the status can be changed to "Done".

The following menu is a vital menu in the production process that is Schedulers menu. On the menu, there are three submenus that Compute Stock Minimum Run Schedulers and Procurements.

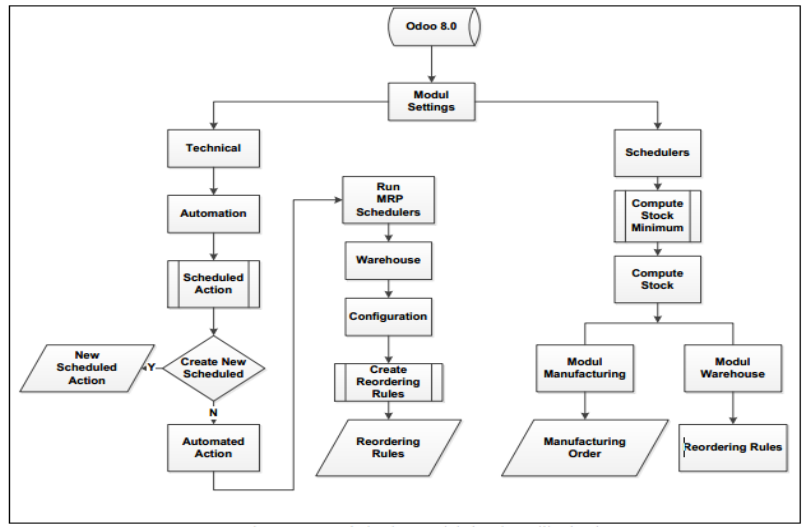

Fig 9: Production Scheduling Workflow on Application

Workflow process of scheduling production on Odoo application found in the Settings menu or setting contains various procedures for set up and configure all the modules contained within the menu along with the application. Measures scheduling can be roughly divided into two processes automatically create production scheduling and scheduling production running.

Process of production scheduling to start automatically begin with access on Module Settings-Technical-Automation Scheduled Action-Create New Scheduled-Schedulers-MRP 
Run Warehouse Configuration-Create Ordering Rules. Furthermore, running production processes that have been made before, where the expected output is the production demands that can be made automatically becomes MO is provided on the module Manufacturing and Reordering Rules are rules created earlier in the process of reordering performed on Warehouse module seen from the minimum stock that available in the warehouse.

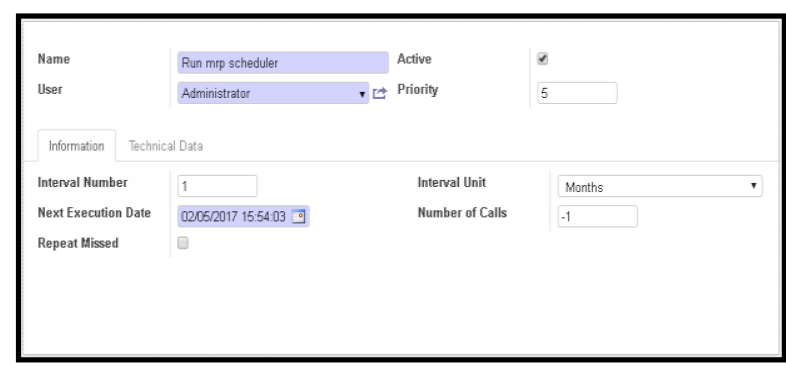

Fig 10: Scheduled Action Form

Scheduled action form used in made a new schedule for production like execution date and interval unit. Every column in this form cant be empty. The other things that must be caution is the rule on making automatic production schedule. The rule in automated action form shown in Figure below.

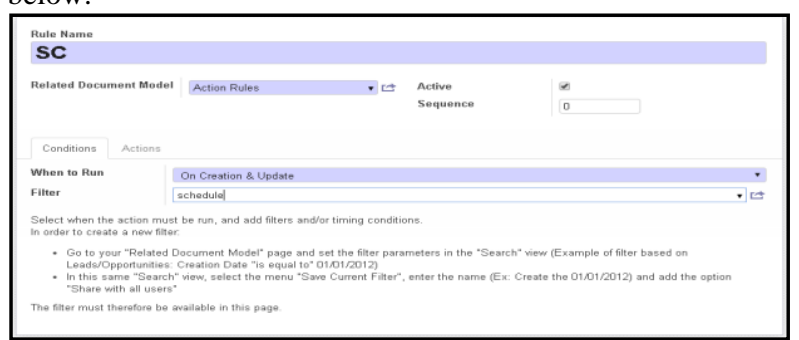

Fig 11: Automated Action Form

After fill Scheduled Action form and making rule in Automated Action form, the next process is how to running the schedulers.

Run Schedulers

Compute all procurements in the background.

\section{Fig 12: Display Menu Run Schedulers}

Menu Run Schedulers when it pressed is to running the schedule that was made on application. This feature computing all the procurement that was made. Another option in production scheduling is checking stock minimum. This feature will describing on the next figure.

Compute Stock Minimum Rules Only

Wizard checks all the stock minimum rules and generate procurement order

Compute Stock or Batal

Fig 13: Display Menu Compute Stock Minimum
Menu Compute Stock Minimum is about checking stock minimum on warehouse and automatically making procurement order if product value out of stock. It can be as a decision if production process needed or not. This feature definitely increasing the efficiency of time and cost. So it also indicating that company can finished customer order ontime or before deadline.

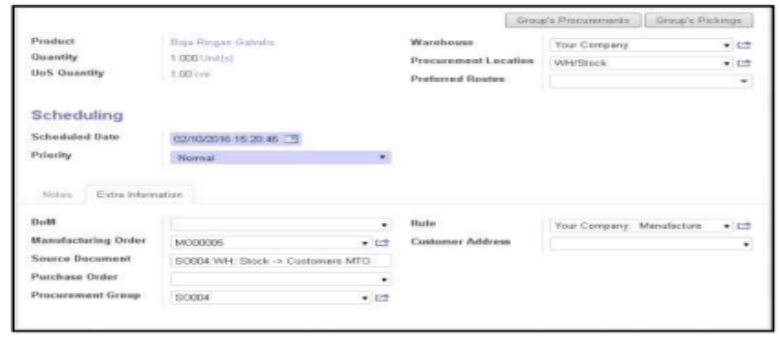

Fig 14: Stock - Customer Make to Order

Procurement orders will automatically appear when there is a production order based Manufacturing Order does not have enough raw materials.

After the automatic production scheduling process is completed, it will make Order Planning that contains a list order request carried to the company.

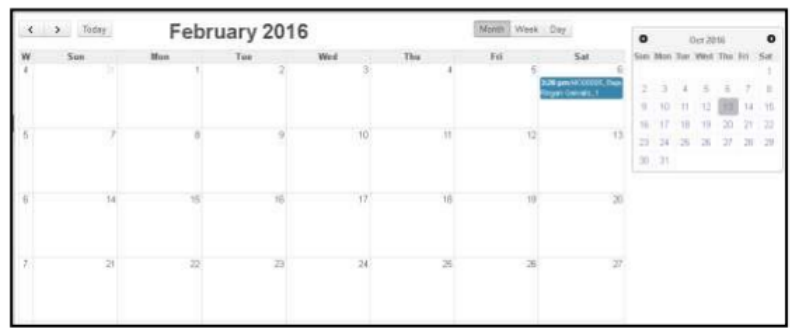

Fig 15: Order Planning display

This menu depends on the number of MO, where at a particular time will appear on that date because the MO is the latest time of the lead time required in the process so that at the time ordered products had to be finished.

\subsection{The Study and Data Analysis}

The Study is step to researching the last business process and how the reengineering business process. After that process, Data Analysis for implementating reengineering business process into workflow or Standart Operating Procedure (SOP) The Study and Data Analysis is to determine the final results of the development that was conducted. Here is the study and data analysis.

\subsubsection{Bussiness Process Reengineering}

Business Process Reengineering was made to repair the old business process management so it can increasing time and cost efficiency. The last business process management using conventional method consist of five modules like Customer, Front Office, Warehouse, Supplier and Production.

Customer cant order product online and must go to the spot. Front Office has so many job include material checking. Every business process worked manually so it must changed into the better workflow business process. Conventional method has many risk like human error. Solution for this problem is redesign business process into better performance in business process. 


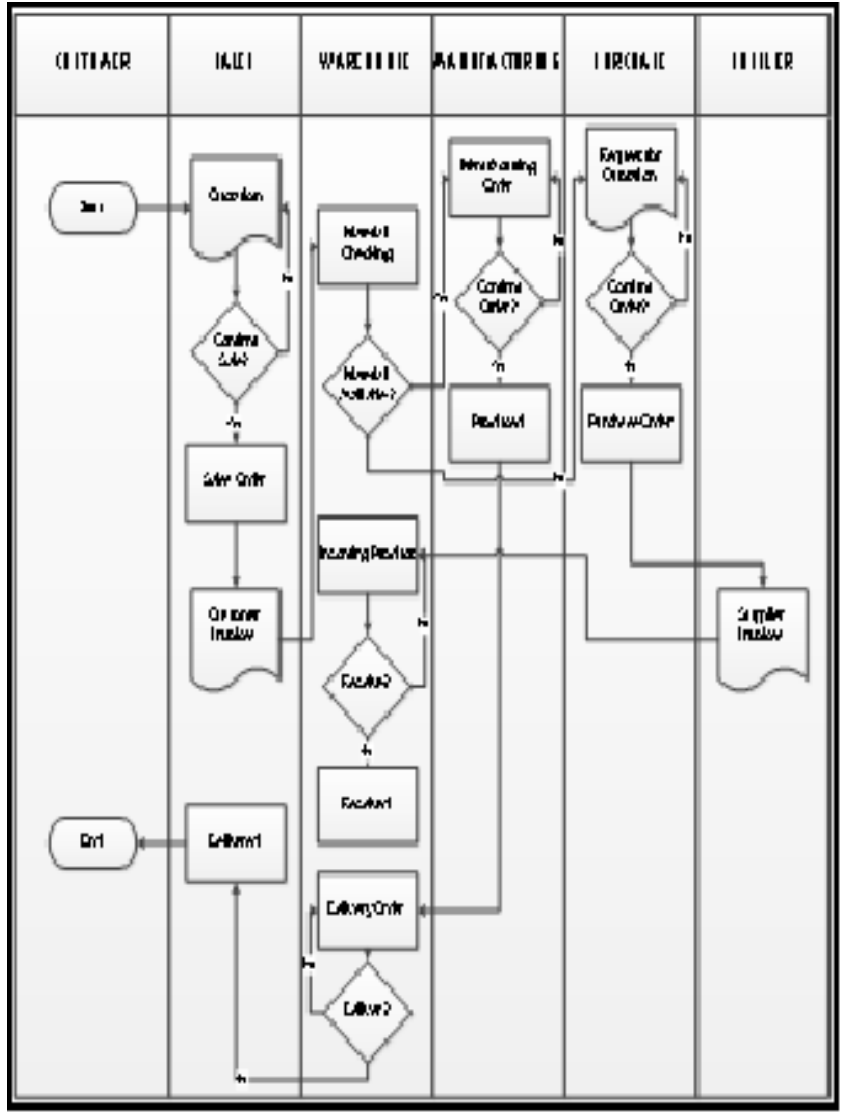

Fig 16. Bussiness Process Reengineering

Bussiness Process Reengineering is redesign based on previous business process management. Step by step not using manual method anymore. Customer can make own order at home or everywhere and everytime they need. After that, each department work on application based on their job until the order completed and delivered to customer.

\subsubsection{Business Process Management on Application}

Implementation on application based on business process reengineering. Workflow business process on application is more structured and it works based on job from each department or module on application.

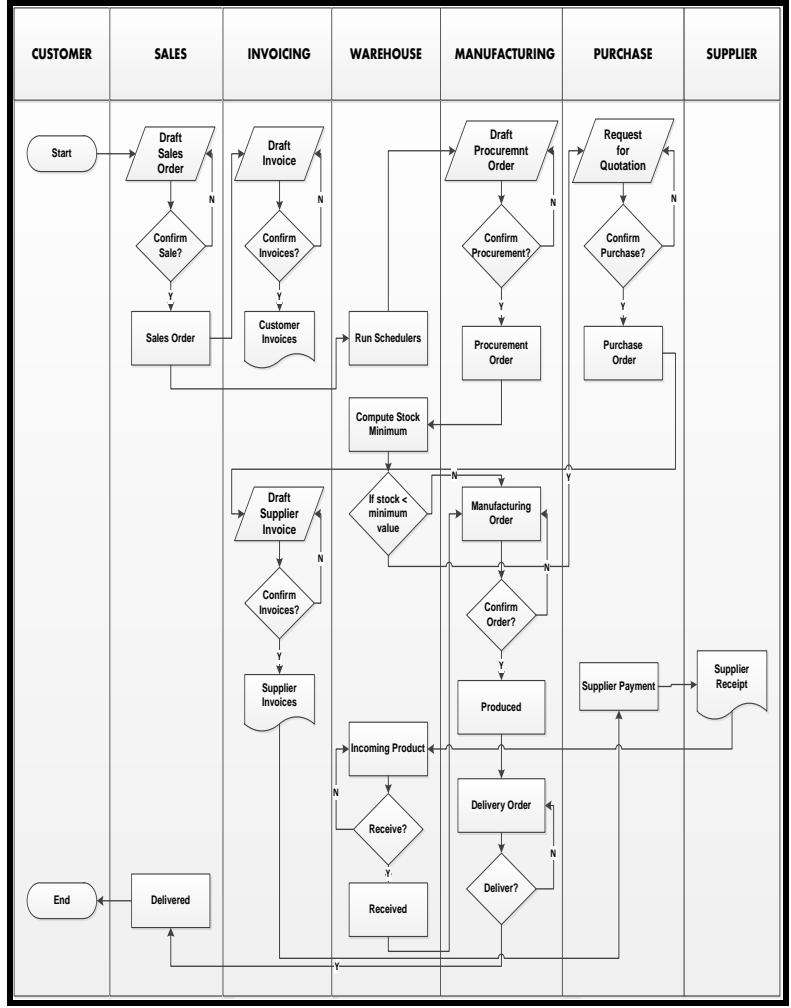

Fig 16. Bussiness Process Management of Application

Figure 3 describes workflow from business process. It has five modules consist of Sales, Invoicing, Warehouse, Manufacturing and Purchases also consist of two entities Customer and Supplier. Every process on application will have draft for validation process by each department based on their purposes before continue to the other process.

\section{CONCLUSION}

Developing manufacturing module application using Enterprise Resource Planning (ERP) concept consists of six stages, namely Literature Research, Data Collecting, Data Processing, Implementation in Odoo, Testing and Implementation System also Conclusion and Suggestion. Development modules using odoo 8.0 version that can customized, user friendly and can handle many business process in one integrated system. The first step is determine business process management and analyzing every single process workflow, if last business process decreasing company perform like don't have any production schedule, business process reengineering is the right choice. The result is implementation of the newest business process on application. Implementation process on Odoo application need customation on manufacturing module for making automatic production schedule that increasing cost and time efficiency.Future scope about the research is how to improvement new modules on application beside manufacturing modules so the application more suitable for every bussines process on different organization.

\section{REFERENCES}

[1] Prawirosentono, Suyadi. 2007. "Manajemen Operasi . Analisis dan Studi Kasus", Edisi Keempat. Jakarta: Bumi Aksara

[2] Morton, T. and Pentico, D. 1993. "Heuristic Scheduling System", Jhon Wiley Interscience.

[3] Dewi, Santi Junita. 2008. "Pengembangan Aplikasi Apotek dengan Menggunakan Konsep Enterprise 
Resource Planning (ERP) Studi Kasus pada Apotek Reza, Bandung”. Departemen Sistem Informasi, Institut Teknologi Harapan Bangsa

[4] Suliyanto. 2005. "Analisis Data dalam Aplikasi Pemasaran". Bogor: Ghalia Indonesia

[5] Lucas, Henry C. Jr. 1987. "Analisis, Desain dan Implementasi Sistem Informasi. Jakarta:Erlangga.

[6] Sumner, Mary. 2005. "Enterprise Resource Planning 1st Edition". Prentice Hall.

[7] Fougatsaro, Vittorio. 2009. "A Study of Open source ERP System”, Paris: School of Management Blekinge Institute of Technology.
[8] Martinich, Joseph S. 1997. "Production and Operations Management. John Wiley \& Sons Inc: Canada

[9] Schroeder, Roger G. 2000. "Operations Management: Contemporary Concept and Cases, International Edition". Mc Graw-Hill Companies Inc: Boston

[10] M. Stoica, et.al. 2003. An Investigation of The Methodologies of Business Process Reengineering. Proc ISECON. vol.20

[11] M. Hammer and J. Champ. 1993. "Reengineering The Corporation: A Manifesto For Business Revolution", New York: Harper Collins publishers. Inc 